\title{
Entrepreneurship Intention to Trigger Entrepreneurship Orientation
}

\author{
Rd. Dian H. Utama, B Lena Nuryanti S., Nani Sutarni \\ Universitas Pendidikan Indonesia \\ dhutama@upi.edu
}

\begin{abstract}
The entrepreneurial orientation in this study is characterized by low interest and lack of student orientation. Entrepreneurship Intention used as a way to improve the entrepreneurial orientation. Objectives of this study are to describe 1) Intension of entrepreneurship in students, 2) Orientation entrepreneurship in students, 3) The amount of influence intention entrepreneurship on entrepreneurship orientation in students. The object of this research is the 70 students of Business Management Education at Universitas Pendidikan Indonesia $2^{\text {nd }}$ grade. The independent variable $(X)$ in this study is the intention of entrepreneurship and the dependent variable $(Y)$ that is entrepreneurial orientation. This type of research is descriptive and verification. The method used in this research is explanatory survey method with the technique of saturated sample, data analysis techniques in this study is used SPSS. The findings in this study are follows: 1) Intention entrepreneurship in the category very high, 2) Orientation entrepreneurship is high, 3) Orientation entrepreneurship was positively affected by intention entrepreneurship. Entrepreneurial intentions amount of $60.4 \%$, where as the remaining $39.6 \%$ is influenced by other variables. Based on these results, it is recommended that orientatuioon entrepreneurship as a basis for other studies regarding the intention entrepreneurship with indicators and different objects.
\end{abstract}

\section{Keywords-Entrepreneurship Orientation, Trigger, Intention of Entrepreneurship,}

\section{INTRODUCTION}

The economy of a country can thrive when the number of entrepreneurs at least 2 percent of the total population of the country. Therefore, in order to increase economic growth in Indonesia, a variety of stakeholders including government massively encourage people to be entrepreneur. Until 2015 the amount entrepreneur at Indonesia in fact is not enough. As quoted in www.republika.co.id, Minister of Cooperatives and SMEs Anak Agung Gede Ngurah Puspayoga said that "number of entrepreneurs at Indonesia is only about 1.65 percent of the population today far less than in neighboring countries. For example Singapore amounted 7\%, Malaysia 5\%, and Thailand 4\%. [1] M.kompasiana.com. Access: 15:50 pm, Friday, October 30, 2015.
Although our country needs more entrepreneurs to create more jobs and encourage economic growth, but in fact building a society with high entrepreneurial spirit is not easy and takes time. Community views regarding entrepreneurship may affect the number of people who choose a life as an entrepreneur, as well as stable political environment and adequate infrastructure. It must be recognized that in general the entrepreneurial culture in our country has not developed as expected, although some regions or ethnicities, professions entrepreneurs occupy a more prominent place.[2]

For some people, being an entrepreneur is identical to the relatively low and irregular income, unclear working hours, and much more mind and energy consuming that are experienced by many entrepreneurs in the early pioneering effort.[3] This is contradictive to the habits owned by many in our society who want to achieve results and success in a short time.[4][5]

The other issue is our education system that gives little encouragement in an entrepreneurial spirit among the young generation, even though nowadays more and more universities introducing the principles and concepts of entrepreneurship.[6] This education focuses more on technical skills purely, but less focused on formation of personality that can support the survival and growth of entrepreneurial spirit like confidence, foresight to see and take advantage of opportunities, charisma building, empathy, and passion to compete to be the best. Likewise skills such as analytical skills, delegating tasks to others, moving others so willing to make efforts to realize the vision and the mission, project management and time management.[7] However, our education system always emphasized the importance of technical skills and a good academic record to get a job easily after graduation, instead of creating new jobs with the profession as an entrepreneur. [8][9].

The growth of entrepreneurship in Indonesia, which is currently still low, is not comparable with number of population Indonesia which is very large.[10] The economy of a nation can be seen from how much entrepreneurs in the country. To create new entrepreneurs, actually universities in Indonesia has great opportunities because besides supports from human resources (HR) is superior, academic environment in the university makes it easier for students to learn and understand the steps and ways to be entrepreneur.[11]

College students are the agent of change that determine future of the nation, whether the nation will go backward or 
forward. To create a great generation not only with a wide variety of course purely theory.[12] But the benefits of college students can be seen also on how much the college students can compete and is able to provide many benefits for the people. Competition here is not only the academic field, but the field wider as entrepreneurs who are currently very encouraged by the government.[13]

Entrepreneur is someone has a creativity for a new business with a courage to risk and uncertainties that aims to achieve a return and business growth by identifying opportunities and able to leverage resources and capitalize this opportunity. [14]. To become an entrepreneur will require clear objectives for the development of business in future. An entrepreneur must has a clear and definite orientation. Orientation entrepreneurship is the ability to create something new and different (ability to create the new and different thing).[15]

The ability of college students in academic only is not enough to be capital being an entrepreneur, because many outstanding students, but instead increase the number of unemployment in Indonesia.[16] This happened because of the mindset of the college students who are educated to pursue a job, not to create jobs. As John Stuart [17] stated that no great progress for humankind before a huge change in the basic constitution of their thinking.

Concept of entrepreneurship initiated in entrepreneurship courses at the University Education Indonesia is expected to improve college students entrepreneurial intentions. [18] Indicated entrepreneurship education with the knowledge and skills required to manage a new venture / start up within a certain period can increase intentions to become entrepreneurs. While [19] describes the experience as an influential factor in the development of preparedness for entrepreneurship.

The learning experience built in entrepreneurship courses are designed in such a possible to equip competence of graduates as planned businesses in the business plan as a result of learning to be achieved by the students, improve attitudes to entrepreneurship by watching movies entrepreneurship theme, and supported by role of institutions allowing achievement of learning objectives entrepreneurship courses at the University of Education Indonesia one of them is the intention of entrepreneurship students.[20]

Based on the description of background research, entrepreneurship intention can be viewed as a strategy to improve the entrepreneurial orientation to create an entrepreneur, so a research with title " Entrepreneurship intention to trigger Entrepreneurship Orientation" is considered needed.

\section{LITERATURE REVIEW}

\section{A. entrepreneurship intentions}

Conceptually, according to Pillis and Reardon, entrepreneurship intentions is tendency starting a new business or venture.[21] Davidson in proceeding entitled Determinants of Entrepreneurial Intentions states that entrepreneurship intention is focused on a person's tendency to start an entrepreneurial activity in the future.[22] While Bird and Jelinek in the journal entitled The Operation of Entrepreneurial Intentions confirms that entrepreneurship intention is a key factor in new activity venture creation, brokered by outside factors such as family background, position in the family, family work, education and exercise.[23]

One theory that has been widely used in measuring entrepreneurship intention is theory of planned behavior initiated by Ajzen [24]. Fayolle, A. Gailly[25] in the conference through a research entitled Using the Theory of Planned Behaviour to Assess Teaching Entrepreneurship Programs which shows that there is strong correlation between entrepreneurship intention with the intention forerunner of the Theory of Planned Behavior or Theory of Planned Behavior propounded by Icek Ajzen.

A major factor in the Theory of Planned Behavior initiated by Ajzen [26] is the intention or tendency of individuals, shown by the behavior are open. The first postulate that the intention is the result of three factors conceptually as described below:

\section{1) Attitudes Toward Behavior}

Attitudes toward behavior is "The degree in which a person has a favorable or unfavorable evaluation or appraisal of the behavior in question".

Attitudes toward behavior refers to the rate at which the individual holds personal assessment of the positive or negative about being an entrepreneur or in performing an entrepreneurial activity.

\section{2) Subjective norms}

Subjective norm is "Perceived social pressures to perform the behavior or not", that views subject of other people's opinions about the proposed behavior. The pressure can be, or not, influential role in its creation or not.

Social norms (Subjective Norm) will measure the perceived social pressure to perform or not perform an entrepreneurial behavior. Specifically, it will lead to the perception that "referral" will approve the decision to become an entrepreneur or not.

\section{3) Perceived Behavioral Control}

Perceived Behavioral Control is unconsciously perceived ease or difficulty of performing behavior. This concept was introduced into the Theory Of Planned Behavior to accommodate the element of volition that is not inherent or potential in a behavior.

Syamsuddin states that teaching and learning process can be defined as a series of interactions between students and teachers to achieve the objectives. Factors affecting entrepreneurship intentions derived from student demographic factors are age, gender, and occupation of parents. While nondemographic factors is the experience in entrepreneurial learning[27] 


\section{B. Orientation Entrepreneurship}

Lumpkin and Dess in Arman Hakim Nasution defines' entrepreneurial orientation as the methods, practices, and decision-making styles used to behave entrepreneur entrepreneurship (entrepreneurial).[28] It is included in the process of experimentation of new technologies, capture new market opportunities, and trends that risk making venture. "Another definition proposed by Messeghem [29] calls entrepreneurship orientation is the ability of companies to look at new business opportunities.

Lumpkin and Dess states that there are five dimensions are a major factor in entrepreneurial orientation, that is:

\section{1) Autonomy}

Autonomy refers to independent actions of individuals or teams in channeling ideas or vision and bring it to completion. [30]

\section{2) Innovation}

Innovation reflects the tendency of companies to be involved in supporting new ideas, experimentation, and creative process that produces the product can, services and new technologies. [31]

\section{3) Risk Taking}

Risks have different meanings, depending on context applied. The attitude of risk-taking is an important component in the entrepreneurial orientation. Cultural environment that can spur a courageous stand in the face of risk will be many more new entrepreneurs who gave birth to the continued, sustainable. [32]

\section{4) proactiveness}

Proactive is an act of anticipating issues, needs and changes in the future. Proactiveness is important for entrepreneurial orientation because it provides a perspective on the future through innovative activities and new business activities. [33]

5) Competitive Aggressive

Competing aggressively refers to the tendency of companies directly and intensely challenging competitors in order to achieve or improve the position, that is with the market leader. [34]

Based on these descriptions, it can be seen that the intentions of entrepreneurship can affect entrepreneurial orientation. The paradigms in this study are:

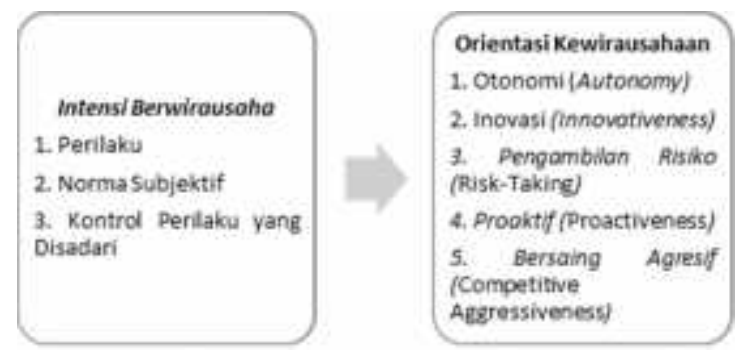

\section{RESEARCH METHODS}

This study uses an entrepreneurial approach, especially regarding the effect on entrepreneurial orientation entrepreneurship intentions. As for the object of study as independent variables (exogenous) is the intention of entrepreneurship $(\mathrm{X})$ with sub behavior, subjective norms and behavior control are realized. Then the research object becoming the dependent variable (endogenous) is an entrepreneurial orientation (Y) which includes Autonomy (Autonomy), Innovation (Innovativeness), Taking Risks (Risk Taking), Proactive (proactiveness), Competitive Aggressive (Competitive aggresiveness). The respondents in this research is the students of Business Management Education Universitas Pendidikan Indonesia.

This research was conducted at the Education University of Indonesia. Based on the period of the research conducted in less than one year, the research method used is cross sectional method. According to Husein Umar [35], "The approach that is a cross sectional research method by studying objects within a certain time or not sustainable in the long term".

Based on level of explanation and research fields, then this type of research is descriptive and verification, with the research method used is explanatory survey. The population in this study were the second year students with the number $\mathrm{N}=$ 70. In this study, the sample size is determined through sampling techniques with saturated sample in which all members of the population sampled.

\section{RESULTS AND DISCUSSION}

\section{A. Discussion Descriptive}

\section{1) Entrepreneurship intention}

Based on empirical research papers on entrepreneurship intentions regarding the implementation of Business Management Education student at the Universitas Pendidikan Indonesia, generated findings shows that the indicator discipline ourselves to realize opportunities have contributed sufficiently high for entrepreneurs in achieving entrepreneurship intentions.

\section{2) Entrepreneurship Orientation}

Table I explains generated findings that innovation dimensions (innovativeness) have contributed sufficiently high to achieve entrepreneurial orientation.

$$
\mathrm{Y}=24.829+0,655 \mathrm{X}
$$

The constant value of 47077.856 states that if there is no entrepreneurial mindset, then the amount of entrepreneurial orientation of 24.829. A regression coefficient of 0.655 of one unit increase in value means that every intention entrepreneurship will increase by 0.655 entrepreneurial orientation of the unit value and vice versa, if the decline in entrepreneurial orientation, entrepreneurship intentions will reduce entrepreneurial orientation of the unit value of 0.655 .

Fig. 1. .The paradigms in this study 
TABLE I. SIMPLE LINEAR REGRESSION MODEL

Coefficients $^{\mathrm{a}}$

\begin{tabular}{|c|c|c|c|c|c|c|}
\hline & \multirow[t]{2}{*}{ Model } & \multicolumn{2}{|c|}{$\begin{array}{l}\text { Unstandard } \\
\text { zed } \\
\text { Coefficients }\end{array}$} & \multirow{2}{*}{\begin{tabular}{|l|}
$\begin{array}{c}\text { Standard } \\
\text { ized } \\
\text { Coefficie } \\
\text { nts }\end{array}$ \\
Beta \\
\end{tabular}} & \multirow[t]{2}{*}{$\mathbf{t}$} & \multirow[t]{2}{*}{ Sig. } \\
\hline & & B & \begin{tabular}{|l} 
Std. \\
Error
\end{tabular} & & & \\
\hline & (Constant) & 24.829 & 9.989 & & 2.486 & .016 \\
\hline 1 & $\begin{array}{l}\text { Intensi } \\
\text { Berwirausa } \\
\text { ha }\end{array}$ & .655 & .071 & .777 & 9.166 & .000 \\
\hline
\end{tabular}

a. Dependent Variable: Orientasi Kewirausahaan

a. Source: Data Processing, 2015

The relationship between entrepreneurship intentions and entrepreneurship orientation obtained from the model summary described in Table II can be calculated the coefficient of determination is:

$$
\begin{aligned}
\mathrm{KD} & =0.604 \times 100 \% \\
\mathrm{KD} & =60.4 \%
\end{aligned}
$$

The result of above calculations shows that coefficient of determination is $60.4 \%$, which means that entrepreneurial orientation are influenced by the entrepreneurial intentions amount of $60.4 \%$, whereas the remaining $39.6 \%$ is influenced by other variables (not examined in this study).

\begin{tabular}{|c|c|c|c|c|c|c|c|c|c|}
\hline \multicolumn{10}{|c|}{ Model Summary ${ }^{b}$} \\
\hline M & \multirow[t]{6}{*}{$\mathrm{R}$} & \multirow{6}{*}{$\begin{array}{l}\mathrm{R} \\
\mathrm{Squ} \\
\text { are }\end{array}$} & \multirow{6}{*}{$\begin{array}{l}\text { Adj } \\
\text { uste } \\
\text { d R } \\
\text { Squ } \\
\text { are }\end{array}$} & \multirow{6}{*}{$\begin{array}{l}\text { Std. } \\
\text { Error } \\
\text { of } \\
\text { the } \\
\text { Esti } \\
\text { mate }\end{array}$} & \multicolumn{5}{|c|}{ Change Statistics } \\
\hline 0 & & & & & \multirow{5}{*}{$\begin{array}{l}\text { R } \\
\text { Squar } \\
\text { e } \\
\text { Chan } \\
\text { ge }\end{array}$} & \multirow{5}{*}{$\begin{array}{l}\text { F } \\
\text { Cha } \\
\text { nge }\end{array}$} & \multirow{5}{*}{$\begin{array}{l}\mathrm{df} \\
1\end{array}$} & \multirow{5}{*}{$\begin{array}{l}\mathrm{df} \\
2\end{array}$} & \multirow{5}{*}{$\begin{array}{l}\text { Sig. } \\
\text { F } \\
\text { Chan } \\
\text { ge }\end{array}$} \\
\hline$d$ & & & & & & & & & \\
\hline el & & & & & & & & & \\
\hline & & & & & & & & & \\
\hline & & & & & & & & & \\
\hline & .77 & .60 & .597 & 15.4 & .604 & 84.0 & 1 & 6 & .000 \\
\hline 1 & $7^{\mathrm{a}}$ & 4 & & & & & & 8 & \\
\hline
\end{tabular}

\section{TABLE II. MODEL SUMMARY}

a. Predictors: (Constant), entrepreneurship intention

b. Dependent Variable: entrepreneurhip orientation

\section{HYPOTHESIS TESTING}

Table III calculation of the t-test with SPSS 21.0 for windows obtained count amounted to 5,059 with significance level of $5 \%$. Compared to table value, acquisition count has a number greater than the value $t$ table $(5,059>1,665)$, then it can be concluded that the null hypothesis (H0) is rejected and Ha accepted. This means that there is a positive influence on entrepreneurial orientation entrepreneurship intentions.

TABLE III. TEST RESULTS T (T-TEST)

\begin{tabular}{|c|c|c|c|c|c|}
\hline \multirow[t]{2}{*}{ Model } & \multicolumn{2}{|c|}{$\begin{array}{l}\text { Unstandardized } \\
\text { Coefficients }\end{array}$} & \multirow{2}{*}{\begin{tabular}{|l|}
$\begin{array}{c}\text { Standardized } \\
\text { Coefficients }\end{array}$ \\
Beta
\end{tabular}} & \multirow[t]{2}{*}{$t$} & \multirow[t]{2}{*}{ Sig. } \\
\hline & B & $\begin{array}{l}\text { Std. } \\
\text { Error }\end{array}$ & & & \\
\hline (Constant) & 47077.856 & 7931.526 & & 5.936 & .000 \\
\hline $\begin{array}{l}{ }^{1} \text { Intensi } \\
\text { Berwirausaha }\end{array}$ & .419 & .083 & .523 & 5.059 & .000 \\
\hline
\end{tabular}

Coefficients $^{\mathrm{a}}$

a. Dependent Variable: Orientasi Kewirausahaan

c. Source: Data Processing, 2015

\section{CONCLUSION}

The discussion of theory, research, and testing of linear regression analysis conducted on the effect of entrepreneurship intentions on entrepreneurship orientation to the students of Business Management Education 2014 Education University of Indonesia can be summed up as follows:

- The study states that the intention of entrepreneurship of the students of Business Management Education 2014 Indonesia University of Education is at a very high category. This shows that the intention of entrepreneurship in Business Management Education's students at Universitas Pendidikan Indonesia has been in a good category. Indicators that have the highest ratings is disciplining yourself to realize acquisition opportunities with a score of 1.814 , while the indicator with the lowest ratings is involving ability other people on the team with the acquisition of a score of 1,751 .

- The study states that entrepreneurial orientation on Business Management Education student at Universitas Pendidikan Indonesia at high category. This shows that the entrepreneurial orientation of the students of Business Management Education 2014 at Indonesia University of Education has been good. Indicator that has the highest ratings is innovation (innovativeness) with the acquisition of a score of 1,826. While indicators which has the lowest ratings is competing aggressively (competitive aggressiveness) with the acquisition of a score of 1,428. 
- The results show that the intention of entrepreneurship has a positive influence on entrepreneurial orientation with a direct influence by $27.3 \%$. This suggests that higher implementation of entrepreneurship intentions, hence excertion also entrepreneurial orientation.

\section{RECOMMENDATION}

- The entrepreneurship intention of Business Management Education students at Universitas Pendidikan Indonesia can be improved by building a mindset of students in terms of involving ability of other people in teams. Indicators involving ability of other people in teams can be improved by creating and maintaining relationships with partners with the aim to create the best opportunities.

- The orientation entrepreneurship of students at Business Management Education, Universitas Pendidikan Indonesia can be improved on competitive aggressiveness. Dimensions competitive aggressiveness can be improved by creating or improving product quality standards so there will be a high value to compete with other products. Addition to enhancing product quality standards, the entrepreneur also needs to improve his/her quality standards by improving the abilities and skills acquired through training programs in entrepreneurship. This is done in order not only to compete, but also to make their products entrepreneur itself able to compete with a competitor business

- The results of this study revealed that entrepreneurship intention gave positive effect on entrepreneurship orientation, the authors recommend to continue improving implementation of the entrepreneurship intention to build entrepreneurship mindset in terms of business management. This can be done with the skill of making a priority scale, frameworks, experiments, and standard-setting success, so workflow and entrepreneurial mindset will be formed.

\section{REFERENCES}

[1] M.kompasiana.com. Access: 15:50 pm, Friday, October 30, 2015

[2] Harris JR. Some problems in indentifying the role of entrepreneurship in economic development: The Nigerian case. Explorations in Economic History. 1970 Feb 28;7(1):347-69.

[3] Hillinger C. Science and ideology in economic, political and social thought. Political and Social Thought (November 2006). 2006 Nov 1.

[4] Diamond J. Collapse: How societies choose to fail or succeed. Penguin; 2005 Dec 27.

[5] Collins JC, Porras JI. Built to last: Successful habits of visionary companies. Random House; 2005.

[6] Lee SM, Peterson SJ. Culture, entrepreneurial orientation, and global competitiveness. Journal of world business. 2001 Feb 28;35(4):401-16.

[7] Clark KB, Wheelwright SC. Organizing and leading" heavyweight" development teams. California management review. 1992 Apr 1;34(3):928.

[8] Goleman D. Working with emotional intelligence. Bantam; 1998.

[9] Susanto, A. B. Leadpreneurship: Pendekatan Strategic Management dalam Kewirausahaan. 2009.
[10] Tambunan T. SME development, economic growth, and government intervention in a developing country: The Indonesian story. Journal of international entrepreneurship. 2008 Dec 1;6(4):147-67.

[11] Banerjee AV, Duflo E. The economic lives of the poor. The journal of economic perspectives. 2007 Jan 1;21(1):141-67.

[12] Lieberson S. A matter of taste: How names, fashions, and culture change. Yale University Press; 2000

[13] Etzkowitz H, Webster A, Gebhardt C, Terra BR. The future of the university and the university of the future: evolution of ivory tower to entrepreneurial paradigm. Research policy. 2000 Feb 29;29(2):313-30.

[14] Yuyus, Suryana. dan Bayu, Kartib. Kewirausahaan: Pendekatan Karakteristik Wirausahawan Sukses. 2010.

[15] Ronstadt R. The educated entrepreneurs: A new era of entrepreneurial education is beginning. Entrepreneurship education: Current developments, future directions. 1990:69-88.

[16] Kirby DA. Entrepreneurship education: can business schools meet the challenge?. Education+ training. 2004 Oct 1;46(8/9):510-9.

[17] Rohmadi, Rusdi. Menjadi Wiraswasta Mandiri. 1995.

[18] Izedonmi. Prince Famous, Chinonye Okafor. The Effect Of Entrepreneurship Education On Students' Entrepreneurial Intentions. Global Journal of Management and Business Research Vol. 10 Issue 6 (Ver 1.0) August 2010 P a g e |49-60

[19] Erikson, T.,Towards a taxonomy of entrepreneurial learning experiences among potential entrepreneurs. Journal of Small Business and Enterprise Development 10(1), 2003.pp. 106-112.

[20] Nteere KK. Determinants influencing the performance of entrepreneurship education in public universities in Kenya (Doctoral dissertation), 2006

[21] Pillis, E. Reardon, K. K. The Influence Of Personality Traits And Persuasive Messages On Entrepreneurial Intention: A Cross-Cultural Comparison. Career Development International, 12(4).2007.pp.382-396.

[22] Davidson, P. Determinants of Entrepreneurial Intentions. In Proceedings RENT XI Workshop, Piacenza, Italy.1995. http://eprints.qut.edu.au/archive/00002076/Retrieved on Sept. 2007

[23] Bird, B. Jelinek, M. The Operation of Entrepreneurial Intentions. Entrepreneurship: Theory and Practice, Vol. 13, No. 2, pp. 21-29.

[24] Ajzen, I. 1991. The Theory of Planned Behaviour. Organizationa Behaviour and Human Decision Processes, Vol. 50,1988. pp.179-211.

[25] Fayolle, A. Gailly B. Using the Theory of Planned Behaviour to Assess Entrepreneurship Teaching Programs: A First Experimentation. 14th Annual IntEnt Conference University of Napoli Federico II-Italy.2004.

[26] Ajzen, I. The Theory of Planned Behaviour. Organizational Behaviour and Human Decision Processes, Vol. 50.1991.

[27] Abin Syamsuddin Makmun. Psikologi Pendidikan. 2005

[28] Arman Hakim Nasution, et al. Entrepreneurshp Membangun Spirit Teknopreneurship.2007

[29] Messaghem, Karim. Strategies Entrepreneurship and Managerial Activities in SMEs. International Business Journal. Vol. 21 No. 2.2003.

[30] Lumpkin G.T. and Dess G.G. Clarifying the Entrepreneurial Orientation Construct and Linking it to Performance, Academy of management review. Vol. 21. No.1, 1996.pp.140

[31] Lumpkin G.T. and Dess G.G.. Clarifying the Entrepreneurial Orientation Construct and Linking it to Performance, Academy of management review. Vol. 21. No.1,1996. pp.142

[32] Arman Hakim Nasution, et al. Entrepreneurshp Membangun Spirit Teknopreneurship.2007.pp.10

[33] Lumpkin G.T. and Dess G.G. Clarifying the Entrepreneurial Orientation Construct and Linking it to Performance, Academy of management review. Vol. 21. No.1, 1996. pp.146

[34] Lumpkin G.T. and Dess G.G. Clarifying the Entrepreneurial Orientation Construct and Linking it to Performance, Academy of management review. Vol. 21. No.1, 1996. pp.148

[35] Husein, Umar. Metode Riset Bisnis. 2008. Pp.45. 